\title{
Evaluation of breastfeeding self-effectiveness and its associated factors in puerperal women assisted at a public health system in Brazil
}

Sebastião Leite Pinto 1

iD https://orcid.org/0000-0003-3349-8717

Ana Carolina Cárnio Barruffini 2

iD https://orcid.org/0000-0002-5612-6409

Vanessa Oliveira Silva 3

iD https://orcid.org/0000-0002-6648-0065

Jéssica Enocêncio Porto Ramos 4

iD https://orcid.org/0000-0001-7961-1151

Isabela Cinquini Junqueira 5

iD https://orcid.org/0000-0003-3774-3409

\author{
Leonardo Luiz Borges 6 \\ iD https://orcid.org/ 0000-0003-2183-3944 \\ Jacqueline Andréia Bernardes Leão Cordeiro 7 \\ (iD https://orcid.org/ 0000-0003-0703-3609 \\ Antonio Márcio Teodoro Cordeiro Silva 8 \\ iD https://orcid.org/0000-0003-0645-3599 \\ Rogério José de Almeida 9 \\ iD https://orcid.org/0000-0002-2150-6057
}

1,2,3,6,8,9 Pontifícia Universidade Católica de Goiás (PUC Goiás). Av. University, 1440. Setor Leste Universitário. Goiania, GO, Brasil. CEP: 74.175-120. E-mail: rogeriopucgo@gmail.com

4,5,7 Universidade Federal de Goiás. Goiania, GO, Brasil.

\begin{abstract}
Objectives: evaluate breastfeeding self-efficacy and its associated factors in puerperal women assisted at a public health system in Brazil.

Methods: it is a cross-sectional analytical study, with convenience sampling and two instruments: sociodemographic, personal and clinical, and Breastfeeding Self-Efficacy Scale (BSES-SF), applied to puerperal women in a puerperal outpatient clinic at two public maternity hospitals in Goiânia/GO, from September to November 2019. Inclusion criteria: mothers in puerperal period, age above 18 years, children born at term and on exclusive breastfeeding. Exclusion criteria: report depression and premature wean.

Results: 128 puerperal women were interviewed. The average age was 26.7 ( \pm 5.9$)$ years old. The levels of self-efficacy were high (95.3\%) and no puerperal had a low level. The variables with statistical significance were: experience in breastfeeding $(p=0.0312)$, not having received information on breastfeeding during pregnancy $(p=0.0292)$, did not receive other milk at the maternity $(p=0.0380)$, did not feel pain while breastfeeding $(p=0.0242)$, being able to breastfeed on demand ( $p=0.0124)$, presence of breast engorgement $(p=0.0207)$, presenting protruding nipples ( $p=0.0427$ ).

Conclusions: clinical and personal aspects were identified as risk factors for early weaning. This can provide information for the training of professionals and structuring the interventions in health services, with a view in preventing these risks.

Key words Maternal breastfeeding, Self-efficacy, Weaning
\end{abstract}

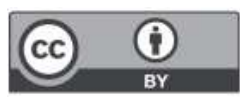




\section{Introduction}

Maternal breastfeeding is a practice to promote health recommended exclusively in the first six months of a child's life, with vast scientific evidence. It is a natural feeding process for mothers and brings many benefits. ${ }^{1}$ Epidemiological and biological findings of the past decade have expanded the wellknown benefits of exclusive breastmilk in the first six months of life for both children and women. ${ }^{2}$

It estimates that the expansion of breastfeeding to an universal level could prevent about 823,000 annual deaths of children under five years old, which would represent a $15.5 \%$ reduction in annual deaths in this age group. In addition, about 20,000 annual deaths from breast cancer could be avoided, corresponding to a $3.2 \%$ decrease in deaths from this type of cancer.2,3

Despite global efforts to implement programs and public policies to encourage breastfeeding, rates of early onset, duration and exclusivity have not yet reached desirable levels. 2,4

It is known that aspects related to premature weaning are associated with sociocultural factors, intrinsic aspects in women's daily life, anatomophysiological characteristics and, especially, the difficulties presented in the breastfeeding process. 5

In this perspective, given the numerous factors that can interfere with breastfeeding, it is essential to identify and test strategies that could help mothers and families to adopt this practice. A path to do this evaluation is through self-efficacy, at the moment of the puerperal follow-up, in which mother and baby must be evaluated and assisted from the perspective of comprehensive care, considering both individual aspects and those that involve family and social context. 6

With this in mind, the focus of this problematization analysis is on breastfeeding self-efficacy in puerperal women undergoing outpatient puerperal follow-up. Therefore, this study aimed to evaluate breastfeeding self-efficacy and its associated factors in postpartum women assisted at a public health system.

\section{Methods}

This is a cross-sectional analytical study with a quantitative approach, ${ }^{7}$ developed through convenience sampling. In this study, conducted at two public maternity hospitals in Goiânia/GO, questionnaires were applied to puerperal women in their first medical appointment after delivery. Data collection at the two maternity hospitals took place between
September and November 2019.

Inclusion criteria were: mothers in the puerperal period, age above 18 years old, children born at term and on exclusive breastfeeding. Exclusion criteria were: report depression and premature wean.

This study was developed with two instruments, a sociodemographic, personal and clinical questionnaire, developed by the researchers, and was composed with 26 questions that search for information about risk factors associated with premature weaning. The second instrument was the Breastfeeding Self-Efficacy Scale-Short Form (BSES-SF). This form was validated in Brazil, 8 in a public maternity hospital in Ceará State. This scale helps the recognition of mothers who are likely to be successful in breastfeeding, providing them with positive reinforcement, as well as those who may have needs for interventions, in order to provide appropriate and effective assistance. 8

The scale consists of 14 items divided into two domains to assess maternal confidence in breastfeeding: technique (items 1, 3, 4, 6, 11, 12, 13 and 14) and intrapersonal thoughts (items $2,5,7,8,9$ and 10). In each item evaluated, study participants assign a variable score, like Likert, ranging from 1 to 5 points. 8,9 Cut points were: Low effectiveness (from 14 to 32 points); Average effectiveness (from 33 to 51 points); and High Effectiveness (from 52 to 70 points). The domain scores range from 14 to 40 (technical) and 14 to 30 (intrapersonal thoughts). In the domains, the higher the score, the greater the self-efficacy for breastfeeding. 8,9

With the collected data, a database was created using the software IBM SPSS Statistics 18 . Subsequently, descriptive statistics were performed, with measures of central tendency for continuous variables, such as mean and median, and absolute and relative percentage frequencies for discrete variables.

Normality test (Kolmogorov-Smirnov) was applied to distinguish parametric and non-parametric distribution, in order to compare stratified data by sociodemographic variables. Mann-Whitney and Kruskal-Wallis tests were applied for non-parametric distributions and Student's t tests and ANOVA for parametric distributions. A $p$-value $\leq 0.05$ was considered statistically significant.

The present study was sent to the Public Health School in the city of Goiânia/GO for an initial consent. After, the project was approved by the Ethical and Research Committee (ERC) from the Pontifícia Universidade Católica de Goiás (PUC Goiás) and by the ERC of Dona Iris Maternity, approval numbers 3,222,979 (March 26, 2019) and 


\section{3,284,147 (April 25, 2019), respectively.}

\section{Results}

Overall, 128 puerperal women were interviewed in their first postpartum medical appointment from two public maternity hospitals, located in Goiânia city, State of Goiás. When breastfeeding self-efficacy was assessed, $95.3 \%$ of postpartum women presented high self-efficacy score. In addition, no puerperal woman had a level classified as low (Table 1).

The average age was $26.7( \pm 5.9)$ years old, ranging from 18 to 41 , the majority studied up to high school $(65.6 \%)$, were married/in a stable relationship (80.5\%), were not working at the time of the interview $(64.8 \%)$ and had recently given birth for the first time (44.5\%) (Table 2).

Regarding to personal aspects, $82.8 \%$ were breastfed and mostly reported having a pregnancy with habitual risk (78.1\%). Most of them had more than five prenatal consultations $(83.6 \%)$ and, during the prenatal/postpartum period, $92.2 \%$ had some guidance and /or support for breastfeeding (Table 3 ).

With respect to clinical aspects related to breastfeeding, $50.8 \%$ started breastfeeding after their newborn's first hour of life and the majority intended to maintain breastfeeding for more than six months (66.4\%); $67.2 \%$ of the participants also reported not feeling pain when breastfeeding. Free breastfeeding demand was reported by $91.4 \%$ of them and nipple fissure was the most frequent complaint (31.3\%), although most participants reported having a protruding nipple (96.1\%) (Table 4).

When comparing sociodemographic data with the general self-efficacy score for breastfeeding and its domains, no significant differences were found (Table 2).

When comparing puerperal women's personal aspects with the general breastfeeding self-efficacy score and its domains, when it was found that puerperal women who reported to breastfeed previously had a higher general self-efficacy score $(p=0.0312)$ and a higher score in intrapersonal thoughts domain $(p=0.0303)$. Women who were not informed at the hospital about breastfeeding, had a higher score in the technical domain $(p=0.0292)$ (Table 3).

Comparing clinical aspects of puerperal women with the general breastfeeding self-efficacy score and its domains, we identified that mothers who breastfed exclusively when at the hospital, that is, with no other type of milk given to their babies, had higher scores in general self-efficacy $(p=0.0380)$ and in technical domain $(p=0.0461)$. Participants who reported not feeling pain during breastfeeding presented a higher general self-efficacy score $(p=0.0242)$ and also a higher intrapersonal thoughts domain ( $p=0.0034)$ (Table 4).

The puerperal women who were breastfeeding on demand had a higher general self-efficacy score $(p=0.0124)$, as well as a higher score in intrapersonal thoughts domain $(p=0.0341)$. Regarding to problems during breastfeeding, a lower score was identified in intrapersonal thoughts domain in participants who reported having nipple lacerations $(p=0.0207)$. On the contrary, puerperal women reported having normal (protruding) nipples had a higher score in intrapersonal thoughts domain $(p=0.0427)$ (Table 4).

\section{Discussão}

The analyzed puerperal women's profile was observed in this study and does not differ from previous studies with this population sample in Brazil10 and revealed a group of women with an average age of $26.7( \pm 5.9)$ years old, who were stayat-home-mothers, married or in a stable relationship and primiparous. A similar profile was described in a study carried out at Hospital Geral de Fortaleza/CE, that used the BSES-SF scale, which identified a group of puerperal women aged between 18 and 25 years old, in a stable relationship and not working at the time of the interview. 11

It is appropriate to delineate the puerperal women's profile because it is known that breastfeeding practices are influenced by several factors, including maternal age. 12 Studies point that women under 20 years of age breastfeed for a shorter period

Table 1

Characterization of breastfeeding self-efficacy levels measured by Breastfeeding Self-Efficacy Scale-Short Form (BSES-SF) 8 for 128 puerperal women who had recently given birth, in their first postpartum medical appointment, Goiânia, Goiás, Brazil, 2019.

\begin{tabular}{lcc}
\hline Self-efficacy $(\mathbf{n}=\mathbf{1 2 8})$ & $\mathbf{N}$ & $\%$ \\
\hline Low (14 to 32 points) & 0 & 0,0 \\
Medium (33 to 51 points) & 6 & 4.7 \\
High (52 to 70 points) & 122 & 95.3 \\
\hline
\end{tabular}


Comparison of breastfeeding self-efficacy levels measured by Breastfeeding Self-Efficacy Scale-Short Form (BSES-SF) 8 and their domains with sociodemographic data from the 128 puerperal women in their first postpartum medical appointment, Goiânia, Goiás, Brazil, 2019.

\begin{tabular}{|c|c|c|c|c|c|c|c|c|}
\hline Variable $(\mathrm{N}=128)$ & $\mathbf{N}$ & $\%$ & \multicolumn{2}{|c|}{ GS } & \multicolumn{2}{|c|}{ TD } & \multicolumn{2}{|c|}{ ITP } \\
\hline \multicolumn{9}{|l|}{ Age (years) } \\
\hline$\leq 25$ & 58 & 45.3 & 63.9 & & 36.7 & & 27.2 & \\
\hline$>25$ & 70 & 54.7 & 64.8 & 0.8071 & 36.9 & 0.6857 & 27.9 & 0.4698 \\
\hline \multicolumn{9}{|l|}{ Schooling } \\
\hline High school & 84 & 65.6 & 64.5 & & 37.0 & & 27.5 & \\
\hline Higher education & 15 & 11.7 & 64.3 & 0.9845 & 37.1 & 0.6215 & 27.3 & 0.9690 \\
\hline \multicolumn{9}{|l|}{ Currently works } \\
\hline Yes & 45 & 35.2 & 64.6 & & 37.0 & & 27.6 & \\
\hline No & 83 & 64.8 & 64.3 & 0.3976 & 36.7 & 0.6772 & 27.6 & 0.9527 \\
\hline \multicolumn{9}{|c|}{ Are you on maternity leave? } \\
\hline Yes & 44 & 34.4 & 64.6 & & 37.1 & & 27.5 & \\
\hline No & 84 & 65.6 & 64.3 & 0.4778 & 36.7 & 0.5623 & 27.6 & 0.8863 \\
\hline \multicolumn{9}{|l|}{ Marital Status } \\
\hline Single & 25 & 19.5 & 64.6 & & 37.1 & & 27.5 & \\
\hline Married & 103 & 80.5 & 64.4 & 0.8168 & 36.8 & 0.6296 & 27.6 & 0.9187 \\
\hline \multicolumn{9}{|l|}{ Number of children } \\
\hline 1 & 57 & 44.5 & 63.7 & & 36.7 & & 27.0 & \\
\hline 2 & 42 & 32.8 & 65.4 & & 37.2 & & 28.2 & \\
\hline
\end{tabular}

GS= General self-efficacy score for breastfeeding; TD= Technical Domain; ITP= Intrapersonal thoughts domain.

compared to women over 30 years of age. 12,13

We also observed that puerperal women who do not work and tend to breastfeed for longer period as the time spent at work affects the breastfeeding process. There are several factors that contribute to this, such as the time spent working out of home and the stress caused by work. 14

Another important breastfeeding factor is parents' marital stability, which is considered a positive influence on the breastfeeding process. 15 Meantime, other study did not observe this association. 16 It is important to mention that cultural aspects and family dynamics are different between these researches (urban Brazil and Ethiopia, respectively), potentially influencing the results. 16

In the present study, puerperal women, in majority, reported having, at least, the minimum number of prenatal consultations recommended (more than five appointments). These consultations are a set of clinical and educational procedures that aim to monitor mother and child health. Correct monitoring on pregnant women allows early detection and treatment of morbidities, reducing premature birth and low birth weight. In addition, correct prenatal care promotes greater success in the breastfeeding process. ${ }^{17}$

Regarding clinical aspects related to breastfeeding, participants of this study reported starting to breastfeed after the newborn's first hour of life and remained breastfeeding on demand. According to World Health Organization (WHO), the ideal breastfeeding includes early initiation and exclusive breastfeeding for the first 6 months of life. 18

Early breastfeeding is defined as the breastfeeding process initiated within one hour after delivery. 18 Premature breastfeeding initiation has several health benefits, such as the increase of the body's ability to defend itself against infections, the reduction of diarrhea and the increase of children's survival rate. 18,19 Neonatal mortality can be reduced by $33 \%$ with early breastfeeding. $18,20,21$

Regarding to breastfeeding on demand, studies 
Comparison of breastfeeding self-efficacy levels measured by Breastfeeding Self-Efficacy Scale-Short Form (BSES-SF) 8 and their domains with personal aspects of the 128 puerperal women in their first postpartum medical appointment, Goiânia, Goiás, Brazil, 2019.

\begin{tabular}{|c|c|c|c|c|c|c|c|c|}
\hline Variable $(\mathrm{N}=128)$ & $\mathbf{N}$ & $\%$ & \multicolumn{2}{|c|}{ GS } & \multicolumn{2}{|c|}{ TD } & \multicolumn{2}{|c|}{ ITP } \\
\hline \multicolumn{9}{|c|}{ Have you breastfed previously? } \\
\hline Yes & 63 & 49.2 & 65.3 & & 37.1 & & 28.2 & \\
\hline No & 65 & 50.8 & 63.5 & 0.0312 & 36.6 & 0.3785 & 27.0 & 0.0303 \\
\hline \multicolumn{9}{|c|}{ Have you been breastfed? } \\
\hline No & 17 & 13.3 & 64.0 & 0.7207 & 36.5 & 0.6188 & 27.5 & 0.9185 \\
\hline Ignored & 5 & 3.9 & 63.8 & & 35.4 & & 28.4 & \\
\hline \multicolumn{9}{|l|}{ Pregnancy risk } \\
\hline Habitual risk & 100 & 78.1 & 64.4 & & 36.8 & & 27.6 & \\
\hline High risk & 28 & 21.9 & 64.3 & 0.9188 & 36.9 & 0.9174 & 27.4 & 0.7778 \\
\hline \multicolumn{9}{|l|}{ Type of delivery } \\
\hline Transvaginal & 74 & $5 ., 8$ & 64.4 & & 36.9 & & 27.5 & \\
\hline C-section & 54 & 42.2 & 64.4 & 0.9906 & 36.8 & 0.8641 & 27.6 & 0.8753 \\
\hline \multicolumn{9}{|c|}{ Have any companion? } \\
\hline Yes & 116 & 90.6 & 64.6 & & 36.9 & & 27.7 & \\
\hline No & 12 & 9.4 & 63.0 & 0.3431 & 36.4 & 0.6421 & 26.6 & 0.2527 \\
\hline \multicolumn{9}{|c|}{ Did you have contact and the } \\
\hline \multicolumn{9}{|l|}{ child's presence? } \\
\hline Yes & 118 & 92.2 & 64.4 & & 36.8 & & 27.6 & \\
\hline No & 15 & 11.7 & 66.5 & 0.1800 & 38.3 & 0.0292 & 28.1 & 0.9174 \\
\hline
\end{tabular}

GS= General self-efficacy score for breastfeeding; TD= Technical Domain; ITP= Intrapersonal thoughts domain.

have shown that this practice is related to mothers previous training during prenatal care, showing the importance of guidance in the continuation of exclusive breastfeeding.22-24 In addition, studies have shown that mothers who breastfeeds on demand to reduce the use of artificial nipples, supplying the newborn with two "hungers": the physiological need for nutrition and the need for suction. 24,25

When evaluated breastfeeding self-efficacy levels showed a high self-efficacy among the puerperal women interviewed (95.3\%). A similar result was found in a study carried out in Guarulhos/SP in which high self-efficacy was found in $82.3 \%$ of the sample population. 6

Pregnant women preparation and guidance for lactation during prenatal care have proven to contribute to the success of breastfeeding. ${ }^{27}$ In the present study, most of the interviewed mothers performed prenatal care correctly, contributing to a high breastfeeding self-efficacy.

During prenatal care in the public service, pregnant women are advised about the numerous benefits of breastfeeding and are guided about the techniques that facilitate the procedure and promote more confidence when breastfeeding, allowing the success of the process. 27,28

It is increasingly important to encourage public breastfeeding policies to assist and guide pregnant women by teaching the correct techniques for breastfeeding, since, in most cases, women have little skill in the face of this practice, and highlight the importance of breastfeeding for puerperal women and the 
Comparison of breastfeeding self-efficacy levels measured by Breastfeeding Self-Efficacy Scale-Short Form (BSES-SF) 8 and their domains with clinical aspects related to breastfeeding of the 128 puerperal women in their first postpartum medical appointment, Goiânia, Goiás, Brazil, 2019.

\begin{tabular}{|c|c|c|c|c|c|c|c|c|}
\hline \multirow[t]{2}{*}{ Variable $(\mathrm{N}=128)$} & \multirow[t]{2}{*}{$\mathbf{N}$} & \multirow[t]{2}{*}{$\%$} & \multicolumn{2}{|c|}{ GS } & \multicolumn{2}{|c|}{ TD } & \multicolumn{2}{|c|}{ ITP } \\
\hline & & & Mean & $p$ & Mean & $p$ & Mean & $p$ \\
\hline \multicolumn{9}{|l|}{ When did you start breastfeeding? } \\
\hline After the first hour of life & 65 & 50.8 & 64.9 & 0.8043 & 36.9 & 0.8017 & 28.0 & 0.3949 \\
\hline \multicolumn{9}{|c|}{ How long do you intend to breastfeed? } \\
\hline$>6$ months & 85 & 66.4 & 64.4 & 0.9672 & 36.8 & 0.7733 & 27.6 & 0.8199 \\
\hline \multicolumn{9}{|c|}{ Another milk was given at the hospital? } \\
\hline Yes & 48 & 37.5 & 63.2 & & 36.2 & & 27.0 & \\
\hline No & 80 & 62.5 & 65.2 & 0.0380 & 37.2 & 0.0461 & 28.0 & 0.3587 \\
\hline \multicolumn{9}{|l|}{ If yes, in what way? } \\
\hline Yes & 42 & 32.8 & 64.0 & & 36.5 & & 27.6 & \\
\hline No & 86 & 67.2 & 64.6 & 0.5939 & 37.0 & 0.3858 & 27.6 & 0.9867 \\
\hline \multicolumn{9}{|c|}{ Do you feel pain when breastfeeding? } \\
\hline Yes & 43 & 33.6 & 62.9 & & 36.5 & & 26.4 & \\
\hline No & 85 & 66.4 & 65.2 & 0.0242 & 37.0 & 0.3628 & 28.2 & 0.0034 \\
\hline \multicolumn{9}{|c|}{ Are you breastfeeding on free demand? } \\
\hline Yes & 117 & 91.4 & 64.8 & & 36.9 & & 27.8 & \\
\hline No & 11 & 8.6 & 60.5 & 0.0124 & 35.6 & 0.2037 & 24.9 & 0.0341 \\
\hline \multicolumn{9}{|l|}{ Problems while breastfeeding? } \\
\hline Normal (protruding) & 123 & 96.1 & 64.6 & & 36.9 & & 27.7 & \\
\hline Other & 5 & 3.9 & 61.0 & 0.1503 & 35.8 & 0.4714 & 25.2 & 0.0427 \\
\hline \multicolumn{9}{|c|}{ Did you have access to help or support? } \\
\hline No & 9 & 7.0 & 67.1 & & 37.8 & & 29.3 & \\
\hline Yes, familiar & 16 & 12.5 & 64.6 & & 37.1 & & 27.6 & \\
\hline Yes, health service & 59 & 46.1 & 63.3 & 0.1064 & 36.3 & 0.3249 & 27.0 & 0.0842 \\
\hline Ignored & 44 & 34.4 & 65.3 & & 37.3 & & 28.0 & \\
\hline
\end{tabular}

$\mathrm{GS}=$ General self-efficacy score for breastfeeding; TD= Technical Domain; ITP= Intrapersonal thoughts domain.

newborns. 27,28

A remarkable moment in Brazil was the launch, in 1981, of the Programa Nacional de Incentivo ao Aleitamento Materno (PNIAM) (National Breastfeeding Incentive Program), instituted with the objective to generate a new mentality regarding breastfeeding and stimulate public policies for breastfeeding promotion, support and incentive. $24,27,28$

When we evaluated the general self-efficacy score and its domains with sociodemographic data, we did not find any significant association. Considering that sociodemographic data are immutable data, this association relies on the region and population analyzed. 11

In the present study, mothers who breastfed previously had a higher score in general self-efficacy and in the intrapersonal thoughts' domain. The pregnancy-puerperal cycle can influence women's willingness to breastfeed, affecting the breastfeeding 
self-efficacy. ${ }^{11,29}$

According to Bandura's theory, self-efficacy beliefs are fueled by inner experiences. Therefore, previous breastfeeding experiences can influence the effectiveness presented in the breastfeeding of the current child. 11,29

We identified that participants who were not informed about breastfeeding when they were in the hospital (11.7\%) demonstrated greater self-efficacy in the technical domain. We also observed that information about maternal breastfeeding $(88.3 \%$ receive information) associated with guidance and support for breastfeeding (92.2\%), offered during prenatal care, had a significant impact on improving self-efficacy in the studied group, even among those who did not receive information about breastfeeding, when they were in the hospital.11,23

According to clinical aspects, we identified that puerperal women who, when in the hospital, exclusively maternal breastfeed and who were breastfeeding on free demand had a higher score for general self-efficacy and technical and intrapersonal domains, respectively. Participants who reported not feeling pain during breastfeeding had a higher score in general self-efficacy and intrapersonal thoughts domain. Puerperal women who do not feel pain when breastfeeding had greater pleasure and satisfaction, with a consequent higher rate of self-efficacy. 30

A lower score was identified in the intrapersonal thoughts domain in participants who reported having nipple lacerations and postpartum women who reported having normal nipples, that is, protruding nipples had a higher score in the intrapersonal thoughts' domain. Puerperal women who experience

\section{References}

1. Grummer-Strawn LM, Rollins N. Summarising the health effects of breastfeeding. Acta Pediatr (Lisboa). 2015; 104:1-2.

2. Victora CG, Bahl R, Barros AJ, França GV, Horton S, Krasevec J, et al. Breastfeeding in the 21 st century: epidemiology, mechanisms, and lifelong effect. Lancet (Amsterdam). 2016;387:475-90.

3. United Nations International Children's Emergency Fund. [Internet]. R: Child Mortality Report 2019. Estimates developed by the UN Inter Agency Group for Child Mortality Estimation; 2019 [cited 2019 nov 2019] Available from: https://childmortality.org/wp-content/uploads/2019/ 10/UN-IGME-Child-Mortality-Report-2019.pdf.

4. Boccolini CS, Boccolini PM, Monteiro FR, Venâncio SI, Giugliani ER.Tendência de indicadores do aleitamento materno no Brasil em três décadas. Rev Saúde Pública. 2017; 51: 1-9. some type of pain during breastfeeding are less effective in the breastfeeding process. 30 Such problems cause discomfort and dissatisfaction during breastfeeding and negatively affectself-efficacy. 30

The present study has as a limitation to the empirical approach adopted, that is, for a broader and deeper analysis of the phenomenon it is necessary to analyze whether the information offered in prenatal care, associated with guidance/support for breastfeeding, demonstrated in this study, would be enough to increase self-efficacy. Other factors that should also be researched is the degree of information assimilation in the immediate postpartum period and what kind of interference we would have in this assimilation when it is offered by several professionals.

Among all the factors associated with early weaning, puerperal care performed in health services is very important. This study provides information that can support actions to promote, protect and support breastfeeding, with breastfeeding self-efficacy is a tool to be used by health professionals.

\section{Author's contribution}

Leite Pinto SL, Barruffini ACC, Silva VO, Ramos JEP, Borges LL, Cordeiro JABL, Silva AMTC and Almeida RJ Participated in the design and planning of the research project, data collection, data analysis and interpretation, writing and final review of the article. Junqueira IC participated in the planning of the research project, data collection, analysis and interpretation of data, translation into English and final review of the article.
5. Sartorio BT, Coca KP, Marcacine KO, Abuchaim ES, Abrão AC. Instrumentos de avaliação do aleitamento materno e seu uso na prática clínica. Rev Gaúcha Enferm (Porto Alegre). 2017; 38:e64675.

6. Andrade RD. Fatores relacionados à saúde da mulher no puerpério e repercussões na saúde da criança. Esc. Anna Nery (Rio de Janeiro). 2015; 19: 181-6.

7. Bastos JL, Duquia RP. Um dos delineamentos mais empregados em epidemiologia: estudo transversal. Sci Med. 2007; 17:229-32.

8. Dodt RCM. Aplicação e validação da breastfeeding selfefficacy scale - short form (BSES-SF) em puérperas [dissertação]. Fortaleza: Universidade Federal do Ceará; 2008.

9. Dodt RC, Ximenes LB, Almeida PC, Oriá MO, Dennis C. Psychometric and maternal sociodemographic assessment 
of the breastfeeding self-efficacy scale - short form in a brazilian sample. Nurse Education in Practice (Gothenburg). 2012; 2: 66-73

10. Santos LA, Lara MO, Lima RC, Rocha AF, Rocha EM, Glória JC, et al. História gestacional e características da assistência pré-natal de puérperas adolescentes e adultas em uma maternidade do interior de Minas Gerais, Brasil CiêncSaúde Coletiva (Rio de Janeiro). 2018;23:617-25.

11. Tavares MC, Aires JS, Dodt CM, Joventino ES, Oriá MO, Ximenes LB. Aplicação da Breastfeeding Self-Efficacy Scale-Short Form a puérperas em alojamento conjunto : um estudo descritivo.Rev Enferm. 2010; 9: 1-13.

12. Sipsma HL, Magriples U, Divney A, Gordon D, Gabzdyl E, Kershaw T. Breastfeeding behavior among adolescents: initiation, duration, and exclusivity. J Adolesc Health(Amsterdam). 2014;53: $394-400$.

13. Wallenborn JT, Joseph AC, Graves WC, Masho SW Prepregnancy Depression and Breastfeeding Duration : A Look at Maternal Age. J Pregnancy (Cairo). 2018; ID: 4825727.

14. Al-Ruzaihan SA, Al-Ghanim AA, Bu-Haimed BM, AlRajeh HK, Al-Subaiee WR, Al-Rowished FH, et al. Effect of maternal occupation on breast feeding among females in Al-Hassa , southeastern region of KSA. J Taibah Univ Med Sci(Riyadh). 2017;12: 235-40.

15. Margotti E, Margotti W. Fatores relacionados ao Aleitamento Materno Exclusivo em bebês nascidos em hospital amigo da criança em uma capital do Norte brasileiro. Saúde Debate (Rio de Janeiro). 2017;41:860-71, 2017

16. Tewabe T, Mandesh A, Gualu T, Alem G, Mekuria G, Zeleke H.Exclusive breastfeeding practice and associated factors among mothers in Motta town, East Gojjam zone, Amhara Regional State, Ethiopia, 2015: A cross-sectional study.Int Breastfeed J (Melbourne). 2017;12:1-7.

17. Silva EP, Lima RT, Osório MM. Impact of educational strategies in low-risk prenatal care: systematic review of randomized clinical trials. Ciênc Saúde Coletiva (Rio de Janeiro). 2016;21: 2935-48

18. Abie BM, Goshu YA. Early initiation of breastfeeding and colostrum feeding among mothers of children aged less than 24 months in Debre Tabor, northwest Ethiopia: A cross-sectional study. BMC Res Notes (Reino Unido). 2019;12:1-6.

19. Oot LA,Sommerfelt E, Sethuraman K, Ross J. Estimating the effect of suboptimal breastfeeding practices on child mortality : a model in profiles for country-level advocacy. Technical Brief - Food and nutrition technical assistance II project, 2015.

Received on July 9, 2020

Final version presented on October 9, 2020

Approved on January 8, 2021
20. Mugadza G, Zvinavashe M, Gumbo FZ, Pedersen S. Early breastfeeding initiation and incidence of neonatal sepsis in Chipinge District Zimbabwe. Int J Contemp Pediatr (Milwaukee). 2017;5:1.

21. Silva JL, Linhares FM, Barros AA, Souza AG, Alves DS, Andrade PO. Fatores associados ao aleitamento materno na primeira hora de vida em um hospital amigo da criança. Texto Contexto Enferm (Florianópolis). 2018;27:e4190017.

22. do Nascimento MB, Reis MA, Franco SC, Issler H, Ferraro AA, Grisi SJ.. Exclusive breastfeeding in Southern Brazil: Prevalence and associated factors. Breastfeed Med (Chicago). 2010;5:79-85.

23. Nascimento VC, Oliveira MI, Alves VH, Silva KS. Associação entre as orientações pré-natais em aleitamento materno e a satisfação com o apoio para amamentar. Rev Bras de Saude Mater Infant. 2013;13:147-59.

24. Silva CM, Pellegrinelli AL, Pereira SC, Passos IR, Santos LC. Práticas educativas segundo os "dez passos para o sucesso do aleitamento materno" em um banco de leite humano. Ciênc Saúde Coletiva. 2017; 22: 1661-71.

25. Moimaz SA, Rocha NB, Garbin AJ, Saliba O. The relation between maternal breast feeding and non-nutritive sucking habits. Ciênc Saúde Coletiva. 2011; 16: 2477-84.

26. Souza EF, Fernandes RA. Autoeficácia na amamentação: Um estudo de coorte. Acta Paul Enferm. 2014; 27: 465-70.

27. Dias LM, Batista AS, Brandão IM, Carvalho FL, Martins FL, Costa DM, et al. Amamentação: Influência familiar e a importância das políticas públicas de aleitamento materno. Saúde em Foco. 2019;11: 634-46.

28. Ferreira HL, Oliveira MF, Bernardo EB, Almeida PC, Aquino PS, Pinheiro AK. Fatores associados à adesão ao aleitamento materno exclusivo. Ciênc Saúde Coletiva. 2018; 23: 683-90.

29. Bandura A, Azzi RG, Polydoro S. Aspectos teóricos sobre a Teoria Social Cognitiva. PsicolEsc Educ (São Paulo). 2008;12:461-62.

30. Poorshaban F, Pakseresht S, Khalesi ZB, Leili N. Factors Associated with Breastfeeding Self-Efficacy of Mothers Within 6 Weeks of Delivery. Journal of Holistic Nursing (New York City). 2017; 27: 27-34. 